\title{
AlGaN-InGaN-GaN NEAR ULTRAVIOLET LIGHT EMITTING DIODE
}

L. Dimitrocenko, J. Grube, P. Kulis, G. Marcins,

B. Polyakov, A. Sarakovskis, M. Springis, I. Tale

Institute of Solid State Physics, University of Latvia, 8 Kengaraga Str., Riga, LV-1063, LATVIA.

\begin{abstract}
A 382-nm InGaN/AlGaN light-emitting diode (LED) was made on a sapphire substrate by metal-organic vapour phase deposition (MOCVD) technique. Growing of the undoped and Si-doped $\mathrm{GaN}$ and $\mathrm{Al}_{\mathrm{x}} \mathrm{Ga}_{1-\mathrm{x}} \mathrm{N}$ monocrystalline layers with a surface roughness of $<1 \mathrm{~nm}$ required for making light emitting devices has been carried out. To enhance the LED emission efficiency, a modified symmetric composition of an active single quantum well (SQW) structure was proposed. In addition to the conventional p-doped AlGaN:Mg electron overflow blocking barrier, an $n$-doped $\mathrm{AlGaN}: \mathrm{Si}$ SQW barrier layer in the structure was formed that was meant to act as an additional electron tunneling barrier.
\end{abstract}

\section{INTRODUCTION}

Since successful commercialization of UV light-emitting diodes (LEDs) by Nichia $[1,2]$ much effort has been devoted to achieve high efficiency of III-nitride UV LEDs. So far, the efficiency of currently available UV LEDs is not high enough for practical applications (e.g. purification of drinking water [3] or solidstate lighting sources replacing light bulbs [4]).

The efficiency of LEDs depends considerably on the lateral flatness of the quantum well $(\mathrm{QW})$ structure and is determined by the roughness of the lower lying layers. A way to improve the overall efficiency of the III-nitride UV LED is to reduce the probability of electron overflow by optimizing its structure [5]. The III-nitride compound semiconductors require relatively large injection currents for operation due to their lower hole concentration, higher series resistance and, as a consequence, lower material gain, which makes the electron overflowing problem more serious for these semiconductors. At present, incorporation of an electron blocking layer (EBL) on the p-side above the multiple quantum well (MQW) is known to effectively alleviate the problem $[6,7]$.

In the present work, the characteristics of undoped $\mathrm{GaN}$, InGaN, $n-\mathrm{GaN}: \mathrm{Si}$, $p$-GaN:Mg, $n$-AlGaN:Si, and $p$-AlGaN:Mg epilayers were studied for various growth temperatures and III-V ratios; the epilayers with reduced surface roughness have been obtained. A near-UV LED with modified AlGaN-InGaN SQW structure is discussed below.

\section{EXPERIMENTAL.}

Undoped GaN, doped GaN:Si, GaN:Mg, undoped InGaN and doped AlGaN:Si alloys were grown using an Aixtron type (AIX 200RF M) low-pressure 
metal organic chemical vapor deposition (MOCVD) system. The samples were grown on a $c$-plane (0001)-faced 2-inch sapphire substrates. The EPICHEM purity trimethylindium (TMIn), trimethylgallium (TMGa) and trimethylaluminium (TMAl) were used as the group-III precursors. Silane $\left(\mathrm{SiH}_{4}\right)$ and bis-cyclopentadienyl magnesiun $\left(\mathrm{Cp}_{2} \mathrm{Mg}\right)$ were taken as the dopants of $n$ - and $p$-type, respectively. The carrier gases $\mathrm{H}_{2}, \mathrm{~N}_{2}$ and $\mathrm{NH}_{3}$ gas serving as the $\mathrm{N}$ precursor were purified up to $\sim 2$ ppb using MYCROLIS membrane filters. The film thickness during the growth was monitored using a laser interferometer.

To obtain photoluminescence characteristics, the samples were mounted in an ARD-D202N RE closed-cycle optical cryostat (the temperature range 6.5-350 K). The photoexcitation was performed using a tunable laser system (the spectral range 210-350 nm) containing an optical parametric oscillator pumped by the third harmonic of YAG:Nd 5 ns laser pulses. The luminescence spectra and decay were monitored using an Andor type SR-303i-B spectrometer (300 1/mm grating) equipped either by an Andor type DU401BV CCD camera or by a multi-channel plate photodetector with a Tektronix TDS684A oscilloscope.

The electroluminescence of the LED was focused at the entry slit of the spectrometer by a UV fiber optics bundle.

The charge carrier concentration was obtained at $300 \mathrm{~K}$ employing the Vander-Pauw technique.

The monitoring of the film surface was performed using a Weeco type CD2 atomic force microscope (AFM).

For all samples the substrates were first treated in hydrogen ambient at $1080{ }^{\circ} \mathrm{C}$, then a $\sim 60 \mathrm{~nm}$ thick $\mathrm{GaN}$ nucleation layer was grown at $500{ }^{\circ} \mathrm{C}$ and $300 \mathrm{mBar}$ pressure, and a $2 \mu \mathrm{m}$ thick undoped GaN buffer layer - at $1050{ }^{\circ} \mathrm{C}$ and $250 \mathrm{mBar}$ pressure. The optimized growth conditions used for all $\mathrm{GaN}$ and $\mathrm{AlGaN}$ epilayers were as follows. The reactor pressure for all undoped and doped AlGaN layers was $50 \mathrm{mBar}$, and for all undoped and doped $\mathrm{GaN}$ layers $250 \mathrm{mBar}$; the growth temperatures: $1050{ }^{\circ} \mathrm{C}$ for a Si-doped $\mathrm{GaN}$ film, $885^{\circ} \mathrm{C}$ for a Mg-doped GaN film, $1050{ }^{\circ} \mathrm{C}$ for a Si-doped $\mathrm{Al}_{0.15} \mathrm{Ga}_{0.85} \mathrm{film}$, and $885^{\circ} \mathrm{C}$ for a Mg-doped $\mathrm{Al}_{0.15} \mathrm{Ga}_{0.85} \mathrm{~N}$ film. The $\mathrm{In}_{0.04} \mathrm{Ga}_{0.96} \mathrm{~N}$ layer for $\mathrm{SQW}$ was grown at $690{ }^{\circ} \mathrm{C}$. After the p-type layer growth, $30 \mathrm{~min}$. heat treatment of the substrates was carried out in ambient $\mathrm{N}_{2}$ atmosphere at $250 \mathrm{mBar}$ pressure and $865^{\circ} \mathrm{C}$ temperature.

To obtain the photoluminescence characteristics of all investigated compositions they were grown on the GaN buffer layer. Figure 1 presents a schematic of the LED structure and the conduction energy bands near the SQW region. For the proposed UV LED, the Si-doped AlGaN and Mg-doped AlGaN layers act as the first and second SQW barrier layers, respectively. The barrier thickness was 2.5 and $40 \mathrm{~nm}$, respectively. The thickness of the $\mathrm{InGaN}$ QW layer was $3.4 \mathrm{~nm}$. Ni-Au was used for the $p$-side ohmic contact and $\mathrm{Al}$ - for the $n$-side ohmic contact.

The Mg-doped AlMgN layer simultaneously served as a known electron blocking layer (EBL) [6,7], whereas the Si-doped AlGaN layer - as the electron tunneling barrier (ETB), proposed for the MQW structures as an additional layer [8]. 




Fig. 1. Schematic structure of the UV-LED: LT $u$-GaN - nucleation layer; $u$-GaN - undoped buffer layer; $n$-GaN - Si-doped GaN contact layer; $n$-AlGaN - Si-doped $\mathrm{Al}_{0.18} \mathrm{Ga}_{0.82} \mathrm{~N}$ barrier layer; InGaN-SQW - undoped $\mathrm{In}_{0.04} \mathrm{Ga}_{0.96} \mathrm{~N}$ QW layer; $p$ - $\mathrm{AlGaN}-\mathrm{Mg}$-doped $\mathrm{Al}_{0,18} \mathrm{Ga}_{0.82} \mathrm{~N}$ barrier layer; $p$-GaN - Mg-doped GaN contact layer.

\section{RESULTS AND DISCUSSION}

The quality of LEDs strongly depends on the density of defects and majority carriers in the device material as well as on the roughness of the layers underlying the QW layer. The carrier density and mobility of the materials used are shown in Table 1. In order to optimize the device design, the AFM and the photoluminescence characteristics of the undoped (u-GaN) buffer layer, Si-doped GaN SQW contact layer and Si-doped AlGaN ETB layer were considered.

Electrical properties of the used materials (obtained by Van-der-Pauw's technique).

The ohmic contacts: Au-Ni (for p-type material) and

Al (for n-type material) annealed for $5 \mathrm{~min}$

in $\mathrm{N}_{2}$ atmosphere at $550^{\circ} \mathrm{C}$ and $650^{\circ} \mathrm{C}$, respectively

\begin{tabular}{|l|c|c|}
\hline \multicolumn{1}{|c|}{ Material } & $\begin{array}{c}\text { Carrier density, } \\
\mathrm{cm}^{-3}\end{array}$ & $\begin{array}{c}\text { Mobility, } \\
\mathrm{cm}^{2} \mathrm{~V}^{-1} \mathrm{~s}^{-1}\end{array}$ \\
\hline$u$-GaN & $4.1 \cdot 10^{17}$ & 280 \\
\hline$n$-GaN:Si & $1.6 \cdot 10^{18}$ & 268 \\
\hline$n$-AlGaN:Si & $6.2 \cdot 10^{18}$ & 22.5 \\
\hline$p$-GaN:Mg & $1.5 \cdot 10^{17}$ & 3.72 \\
\hline
\end{tabular}

Figure 2 presents the AFM $5 \times 5 \mu \mathrm{m}$ images of the $u$-GaN buffer layer, the $\mathrm{GaN}$ :Si layer and the $\mathrm{A}_{0.18} \mathrm{Ga}_{0.82} \mathrm{~N}$ :Si layer (each grown on the buffer layer). 


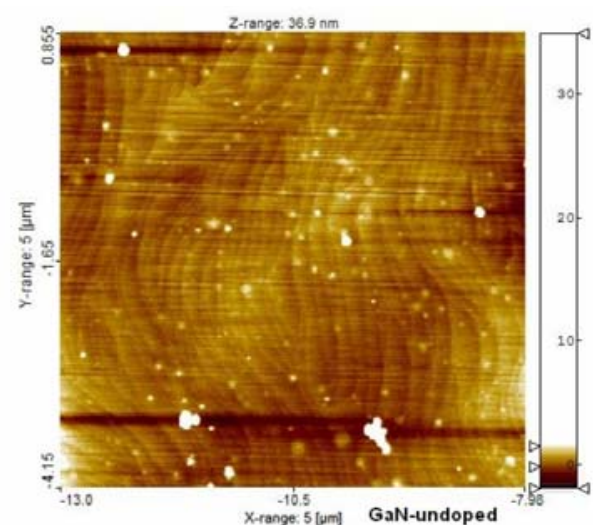

a

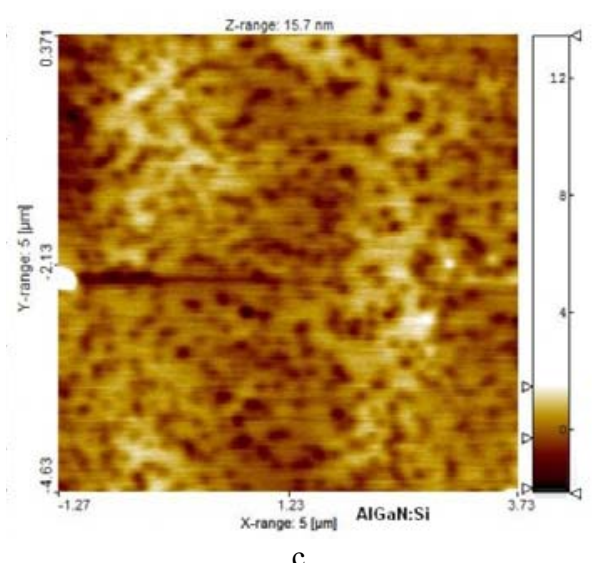

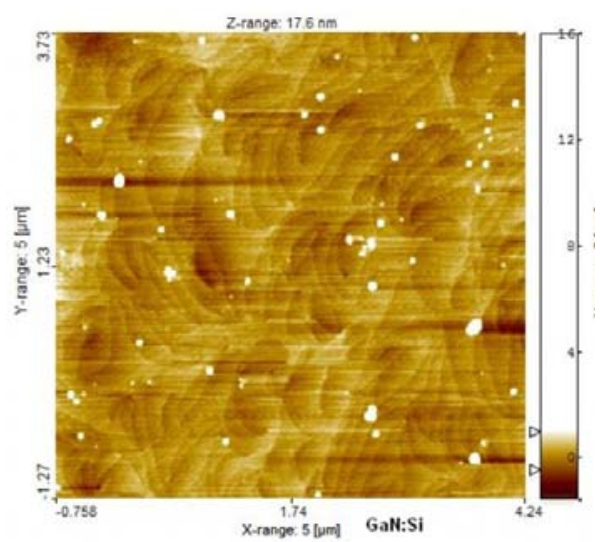

b

Fig. 2. The AFM images of $5 \times 5 \mu \mathrm{m}$ surface of a $3 \mu \mathrm{m}$ thick undoped GaN film $(a) ; 2 \mu \mathrm{m}$ $\mathrm{GaN}: \mathrm{Si}(b)$; and $1.25 \mu \mathrm{m} \mathrm{Al}_{0.18} \mathrm{Ga}_{0.82} \mathrm{~N}: \mathrm{Si}(c)$.

The AFM measurements show that for both the $3 \mu \mathrm{m}$ thick $\mathrm{u}-\mathrm{GaN}$ and the $2 \mu \mathrm{m}$ thick GaN:Si samples a stack of single atom layers can be clearly resolved on the surface. The root-mean-squares of the monocrystalline epilayers are $\mathrm{Sq}=$ $=0.99 \mathrm{~nm}$ for $\mathrm{u}-\mathrm{GaN}$ and $\mathrm{Sq} 3.6 \mathrm{~nm}$ for Si-doped GaN. The roughness of the surface is less than the typical width of the QW. The Si doping of the $1.25 \mu \mathrm{m}$ $\mathrm{Al}_{0.18} \mathrm{Ga}_{0.82} \mathrm{~N}$ layer on $\mathrm{u}-\mathrm{GaN}$ does not lead to increase in the root-mean-squares with respect to the Si-doped GaN. About $1.5 \mathrm{~nm}$ deep pores appear on the layer surface. Obviously, Si doping enhances the lattice mismatch caused by stress in the GaN-AlGaN interface. However, it could be expected that in the initial stage of the AlGaN film growth (several $\mathrm{nm}$ ) the formation of pores will be negligible.

The low-temperature spectroscopy of exciton and defect-related recombination processes was carried out mostly at $10 \mathrm{~K}$.

The PL spectrum of the $3 \mu \mathrm{m}$ thick $\mathrm{u}-\mathrm{GaN}$ buffer layer is presented in Fig $3 a$. The main observed luminescence bands are at $3.48 \mathrm{eV}$ and $3.39 \mathrm{eV}$. The former band corresponds to the doublet involving a donor bound exciton (DBE) and a free exciton (FE). The $3.39 \mathrm{eV}$ band is the FE longitudinal optical phonon replica [9]. Apart from the near band-edge emission, four weak sub-bands at $3.25 \mathrm{eV}$, $3.19 \mathrm{eV}, 3.10 \mathrm{eV}$ and $3.01 \mathrm{eV}$ appear. They correspond to the blue luminescence (BL) band often observed at room temperatures (RT) in undoped $\mathrm{GaN}$, which is attributed to either the shallow DBE or the donor - deep acceptor recombination 
[10]. The reason for the weak BL intensity is low concentration of defects responsible for the acceptor states.

The PL spectrum of the $2.0 \mu \mathrm{m}$ thick Si-doped GaN layer grown on the 2.0 buffer layer (see Fig. $3 b$ ) at $10 \mathrm{~K}$ shows enhanced intensity of the defect-related bands and considerable decrease in the exciton PL. A wide unresolved yellow (YL) band appears in the $h v=2.0-2.9 \mathrm{eV}$ region observed at RT in the unintentionally doped GaN films [11]. The BL lines coincide with those in the undoped GaN.

Among native defects, the Ga vacancies are predicted to dominate in the $n$ type $\mathrm{GaN}$ due to their low formation energy. However, isolated vacancies are mobile at typical temperatures of the growth. Since the $\left(\mathrm{V}_{\text {cation }}-\mathrm{Si}_{\mathrm{Ga}}\right)^{2-}$ has the lowest formation energy with respect to Fermi's energy, the origin of the YL in Sidoped $\mathrm{GaN}$ is assigned to the transitions from a shallow donor to the $\left(\mathrm{V}_{\mathrm{Ga}}-\mathrm{Si}_{\mathrm{Ga}}\right)^{2-}$ complex acceptor [12]. Our PL data show that the doping leads to the simultaneous appearance of YL and BL bands at comparable intensities. Thus, simultaneously with the formation of $\left(\mathrm{V}_{\mathrm{Ga}}-\mathrm{Si}_{\mathrm{Ga}}\right)$ acceptor centres, the concentration of isolated $\mathrm{V}_{\mathrm{Ga}}$ centres responsible for appearance of BL lines also increases. Obviously, the concentration of negatively charged single $\mathrm{V}_{\mathrm{Ga}}$ acceptors will be determined by equilibrium between the negatively charged $\left(\mathrm{V}_{\mathrm{G}}-\mathrm{Si}_{\mathrm{Ga}}\right)$ complexes and the concentration of positively charged single $\mathrm{Si}_{\mathrm{Ga}}$ shallow donors at the growth temperature.

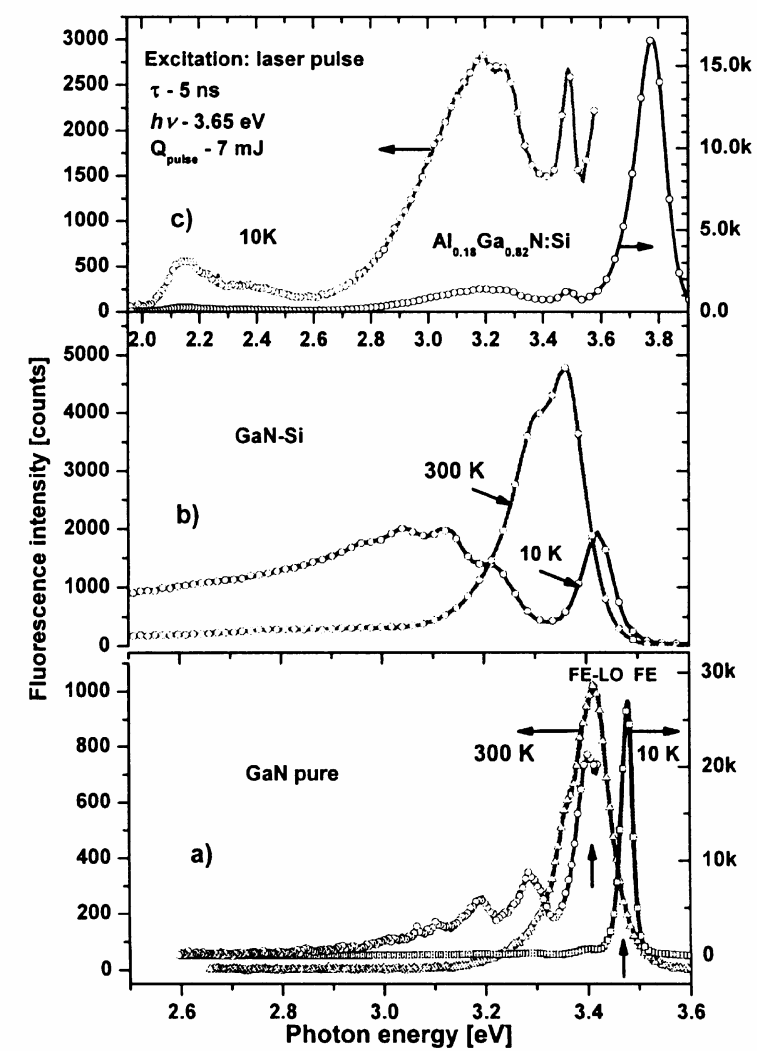

Fig. 3. The photoluminescence spectra of $\mathrm{GaN}$ and $\mathrm{AlGaN}$ thin films excited by $5 \mathrm{~ns}$ laser pulses. a) pure GaN buffer layer grown at $10 \mathrm{~K}$ and $300 \mathrm{~K} ; b$ ) Si-doped GaN contact layer deposited on the $\mathrm{GaN}$ buffer layer at $10 \mathrm{~K}$ and $300 \mathrm{~K}$; c) Si-doped $\mathrm{Al}_{0.18} \mathrm{Ga}_{0.82} \mathrm{~N}$ SQW barrier layer deposited on $\mathrm{GaN}$ buffer layer at $10 \mathrm{~K}$. 
Figure $3 c$ shows the PL spectrum of $1.25 \mu \mathrm{m} \mathrm{Al}_{0.18} \mathrm{Ga}_{0.82} \mathrm{~N}$ :Si alloy deposited on undoped $\mathrm{GaN}$ buffer layer. Owing to the excitation above the band gap at $4.5 \mathrm{~V}$, apart from the broadened exciton band of $\mathrm{AlGaN}$ at $3.88 \mathrm{eV}$, a GaN FE band at $3.48 \mathrm{eV}$ appears in the PL spectrum. The BL band is resolved in two sub-bands at $3.26 \mathrm{eV}$ and $3.19 \mathrm{eV}$. The YL band is represented by two new sub-bands at $2.37 \mathrm{eV}$ and $2.14 \mathrm{eV}$. We propose that in the case of Al-Ga alloy several compositional acceptor $\left[\mathrm{V}_{\text {cation }}-\mathrm{Si}_{\text {cation }}\right]$ complexes are involved in the donor-acceptor pair recombination.

The ohmic contact to the $n$-layer of a 2 -inch LED structure was obtained by deposition of $1.5 \mathrm{~mm} \mathrm{Al}$ on the $2 \mathrm{~mm} n$-layer opened by mechanical polishing using diamond abrasive. Several $\phi 1.5 \mathrm{~mm} \mathrm{Au}-\mathrm{Ni}$ contacts were deposited on the $p$-type GaN layer and subsequently annealed at $5{ }^{\circ} \mathrm{C}$. The electrical and optical LED parameters were measured under the condition of a $\mathrm{CW}$ injection current at RT.

The LED shows a strong emission peak in the 382-388 nm range depending on the injection current. The low wavelength shift at high injection currents may be caused by the increase in the SQW local temperature. The emission spectra are affected by the emission interference in the 2D SQW structure.

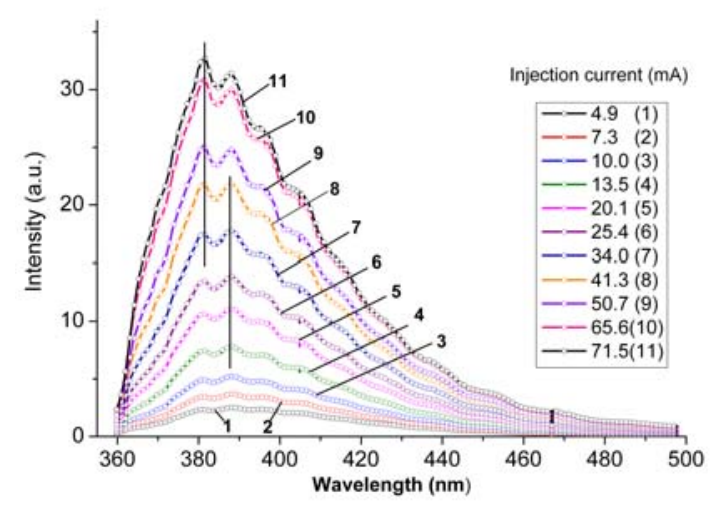

Fig. 4. Electroluminescence spectra of the GaInN LED with AlGaN-InGaN SQW at RT and different injection currents (mA) for the $\phi 1.5 \mathrm{~mm}$ top contact (in the insert). The emission spectra show interference in the SQW 2D structure.

The extended long wavelength tail of electroluminescence spectra up to 500 is typical of LEDs. The short wavelength limit of electroluminescence corresponds to the absorption edge of GaN. Both the BL and the YL are absent in the EL spectra. Thus, the injected charge carrier recombination occurs only in the QW region.

Figure 5 (curve 1) shows the light output power of the obtained LED as a function of the injection current up to $70 \mathrm{~mA}$. Curve 2 shows the current-voltage dependence. Up to $\sim 40 \mathrm{~mA}$, the output power increases linearly with the injection current. The sublinear increase in this parameter indicates that a non-radiative $e-p$ recombination arises at a further increase in the injection current.

Figure 6 shows the electroluminescent emission around the $p$-contact of the UV-LED structure. 




Fig. 5. The power output (1) and the applied voltage (2) as functions of the injection current under CW operation at RT.

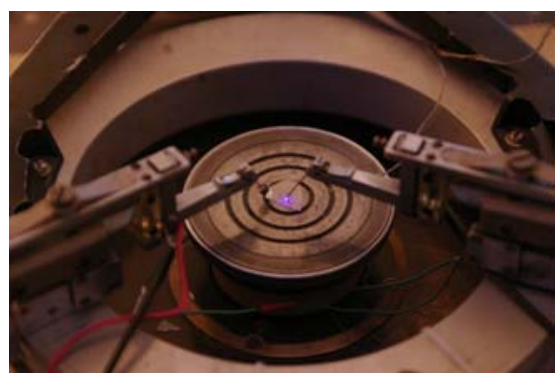

Fig. 6. The image of UV-VIS light emission around the $p$-contact of the LED multilayer structure obtained during $\mathrm{CW}$ operation.

\section{CONCLUSION}

A UV-LED with the emission at $382 \mathrm{~nm}$ has been successfully made. Our data indicate that the use of high-quality undoped and Si-doped GaN layers with low surface roughness which are underlying the active SQW structure allows for making UV-LEDs with a high performance. The composition including both a Sidoped and a Mg-doped barrier layers with low Al content prevents the charge carriers from tunneling directly in the opposite $n$ - and $p$-contact layers. Suppression of the corresponding leakage currents in the SQW UV-LED structure is important to enable the emission with a high output power.

\section{ACKNOWLEDGEMENT}

The paper is granted by the ERAF project Nr. VPD1/ERAF/CFLA/ 05/APK/ 2.5.1./000067/034.

\section{REFERENCES}

1. Khan, M.A., Kuznia, J.N., Bhattarai, A.R., \& Olson, D.T. (1993). Appl. Phys. Lett., 62, 1786.

2. Akasaki, I., \& Amano, H. (1997). Jpn. J. Appl. Phys., 36, 5393.

3. Shatolov, M., Zhang, J., Chitnis, A.S., Adivarahan, V., Yang, J., Simin, G., \& Khan, M.A. (2002). IEEE J. Selected Top. Quantum Electron., 8, 302. 
4. Steigerwald, D.A., Bhat, J.C., Collins, D., Fletcher, R.M., Holcomb, M.O., Ludowise, M.J., Martin, P.S., \& Rudaz, S.L. (2002). IEEE J. Selected Top. Quantum Electron., 8, 310.

5. Domen, K., Soejima, R., Kuramata, A., \& Tanahashi, T. (1998). MRS Internet J. Nitride Semicond.Res.3, (Article 2).

6. Iga, K., Uenohara, H., \& Koyama, F. (1986). Electron. Lett., 22, 1008.

7. Huh, C., Lee, J.M., Kim, D.J., \& Park, S.J. (2002). J. Appl. Phys. 92, 2248.

8. Kim, T.G., Kim, K.C., Kim, D.H., Yoon, S.H., Lee, J.W., Sone, C.S. \& Park, Y.J. (2004). J. Crystal Growth, 272, 264.

9. Reshshikov, M.A., Jasinski, J., Liliental-Weber, Z., Huang, D., He, L., Visconti, P., \& Morkoc, H. (2003). Physica B 340-242, 440.

10. Reshchikov, M.A., \& Morkoc, H. (2006). Physica B 376-377, 428.

11. Mattila, T., \& Nieminen, R.M. (1997). Phys. Rev. B 55, 9571.

12. Limpijumnong, S., \& Van de Walle, C.G. (2004). Phys Rev. B 69, 035207.

\section{AlGaN-InGaN-GaN GAISMAS DIODE TUVAJAM ULTRAVIOLETAM RAJONAM}

L. Dimitrocenko, J. Grube, P. Kulis, G. Marcins,

B. Polyakov, A. Sarakovskis, M. Springis, I. Tāle

K o p s a vi $1 \mathrm{ku} \mathrm{m} \mathrm{s}$

Izmantojot metālorganikas ķīmisko tvaiku uzklāšanas metodi (MOCVD) uz safïra pamatnes, izveidota InGaN/AlGaN gaismas diode (LED) ar emisijas maksimumu pie $382 \mathrm{~nm}$. Izstrādāta metodika monokristālisku neleǵētu, Si- un Mgdopētu $\mathrm{GaN}$ un $\mathrm{Al}_{\mathrm{x}} \mathrm{Ga}_{1-\mathrm{x}} \mathrm{N}$, kur $\mathrm{x}<0.3$ slāņu audzēšanai ar virsmas raupjumu mazāku par $1 \mathrm{~nm}$, kuri nepieciešami LED multislāṇu struktūras audzēšanai. Lai palielinātu LED gaismas emisijas efektivitāti, izveidota modificēta vienas kvantu akas (SQW) struktūra. Papildus konvenciālam p-leǵētam AlGaN:Mg elektronu pārplūšanu bloķējošam barjēras slānim SQW ietverts n-dopēts AlGaN:Si barjeras slānis, kurš rada papildus elektronu tunelēšanas barjeru.

14.07.2008 